\title{
Faktor Risiko Terjadinya Coronavirus Disease 2019 pada Pasien dengan Komorbid Diabetes Melitus
}

\author{
Nikma Syalsabiela Fauzia \\ Program Studi Pendidikan Dokter, Universitas Lampung, nikmasf@gmail.com
}

\begin{abstract}
ABSTRAK
Corona virus disease 2019 (COVID-19) adalah penyakit infeksi severe acute respiratory Syndrome Coronavirus-2 (SARS-CoV-2). Cakupan klinis Covid-19 bervariasi, dari asimptomatik, gejala ringan, hingga kondisi klinis yang ditandai dengan gagal napas akut. Penyakit penyerta tersering pada penderita COVID-19 adalah hipertensi (HTN) $(56,2 \%)$, diikuti oleh diabetes melitus (DM) (30,1\%), dan penyakit ginjal kronis (PGK) (17,5\%). Beberapa studi menyebutkan bahwa diabetes merupakan salah satu faktor risiko utama COVID-19. Oleh karena itu, literature review ini bertujuan untuk mengetahui faktor risiko terjadinya COVID-19 pada pasien diabetes melitus agar dapat digunakan sebagai pertimbangan pengendalian faktor risiko serta perawatan pasien COVID-19 dengan komorbid dapat dilakukan dengan lebih baik. Metode yang digunakan dalam penelitian ini adalah literature review dan penelusuran literatur dilakukan melalui database NCBI, PubMed, dan Google Scholar. Penelitian ini melibatkan sebanyak 24 sumber pustaka dari tahun 2020-2021. Dari beberapa penelitian menyebutkan bahwa diabetes mellitus merupakan faktor risiko utama COVID-19. Kondisi ini terkait dengan beberapa komplikasi makrovaskular dan mikrovaskuler yang pada akhirnya berdampak pada kelangsungan hidup pasien. Diabetes yang merupakan kondisi hiperinflamasi yang dapat meningkatkan kerentanan terhadap COVID-19 dengan kemungkinan mekanisme peradangan kronis, keadaan hiperkoagulasi, dan aktivasi sistem reninangiotensin-aldosteron (RAAS) dan disregulasi sistem saraf simpatis. Penelitian di masa depan sangat diperlukan untuk memberikan pemahaman yang lebih baik mengenai mekanisme patofisiologis yang mendasari hubungan antara COVID-19 dan diabetes, dan manajemen klinisnya.
\end{abstract}

Kata kunci: COVID-19, komorbid, diabetes mellitus, faktor risiko

\begin{abstract}
Corona virus disease 2019 (COVID-19) is an infectious disease severe acute respiratory syndrome coronavirus-2 (SARS-CoV-2). The clinical scope of Covid-19 varies, from asymptomatic, mild symptoms, to clinical conditions characterized by acute respiratory failure. The most common comorbidities in patients with COVID-19 were hypertension (HTN) (56.2\%), followed by diabetes mellitus (DM) (30.1\%), and chronic kidney disease (CKD) (17.5\%). Several studies suggest that diabetes is one of the main risk factors for COVID-19. Therefore, this literature review aims to determine the risk factors for the occurrence of COVID-19 in patients with diabetes mellitus so that it can be used as a consideration for controlling risk factors and better treatment of COVID-19 patients with comorbidities. The method used in this research is literature review and literature search is carried out through the NCBI, PubMed, and Google Scholar databases. This research involves as many as 24 library sources from 2020-2021. Several studies have shown that diabetes mellitus is a major risk factor for COVID-19. This condition is associated with several macrovascular and microvascular complications that ultimately impact the patient's survival. Diabetes which is a hyperinflammatory condition that can increase susceptibility to COVID-19 with possible mechanisms of chronic inflammation, hypercoagulable state, and activation of the renin-angiotensinaldosterone system (RAAS) and dysregulation of the sympathetic nervous system. Future research is urgently needed to provide a better understanding of the pathophysiological mechanisms underlying the association between COVID-19 and diabetes, and their clinical management.
\end{abstract}

Keywords: COVID-19, comorbidities, diabetes mellitus, risk factors

Korespondensi Author: Nikma Syalsabiela Fauzia, Mahasiswa Program Studi Pendidikan Dokter, Universitas Lampung,nikmasf@gmail.com, Telp.082389742739/0895640445516

\section{PENDAHULUAN}

Corona virus disease 2019 atau yang biasa dikenal dengan COVID-19 adalah penyakit infeksi severe acute respiratory Syndrome Coronavirus-2 (SARS-CoV-2). Pada awalnya serangkaian penyakit pneumonia yang sulit dijelaskan terjadi di Wuhan, Hubei, China pada Desember 2020. China melaporkan adanya 44 pasien dengan pneumonia berat yang berkaitan dengan pasar ikan di wilayah tersebut. ${ }^{1}$ Setelah dilakukan pemeriksaan sampel, pada 10 Januari 2020 dilaporkan hasil pemeriksaan sampel tersebut yaitu adanya infeksi virus Corona RNA $\beta$ jenis baru. ${ }^{2}$ Virus 
tersebut dapat menyebar dari orang ke orang dan telah menyebar luas di 219 negara. Pada 12 Maret 2020, Organisasi Kesehatan Dunia menyatakan COVID-19 sebagai pandemi. Pertama kali dilaporkan di Indonesia COVID-19 pada 2 Maret 2020, dan ada dua kasus yang dikonfirmasi di Jakarta. ${ }^{3}$

Manifestasi klinis infeksi SARS-CoV-2 dan SARS-CoV serta MERS-CoV memiliki beberapa kesamaan, yaitu demam, batuk kering, dan gambaran opasifikasi ground-glass pada foto toraks. Cakupan klinis Covid-19 bervariasi , dari tanpa gejala, gejala yang ringan, sampai gejala klinis yang ditandai adanya gagal napas akut, yang memerlukan penggunaan ventilasi mekanis dan dukungan di unit perawatan intensif (ICU). ${ }^{4}$ Faktor risiko infeksi SARSCoV-2 diantaranya usia, jenis kelamin, genetika, dan penyakit komorbid sebagai akibat dari gaya hidup yang tidak sehat yaitu hipertensi, diabetes, penyakit kardiovaskular, penyakit paru-paru dan penyakit penyerta lainnya. ${ }^{5}$ Adanya faktor risiko tersebut juga mempengaruhi tingkat keparahan COVID-19. Ditemukan bahwa tingkat kematian akibat COVID-19 meningkat pada pasien dengan penyakit penyerta. Angka kematian (CFR) adalah $10,5 \%$ untuk penderita penyakit kardiovaskular, 7,3\% untuk penderita diabetes, $6,3 \%$ untuk penderita penyakit pernafasan kronis, $6 \%$ untuk penderita hipertensi, dan 5,6\% untuk penderita kanker. ${ }^{6}$

Penyakit penyerta tersering pada penderita COVID-19 adalah hipertensi (HTN) (56,2\%), diikuti oleh diabetes melitus (DM) $(30,1 \%)$, dan penyakit ginjal kronis (PGK) $(17,5 \%) .{ }^{7}$ Diabetes melitus merupakan gangguan metabolisme yang mempengaruhi peran insulin didalam penyerapan glukosa dalam tubuh. Diabetes mellitus (DM) juga merupakan ancaman bagi kesehatan dunia, dan tingkat keparahannya telah meningkat pada 20 tahun ini. ${ }^{8}$ Penderita DM rentan terhadap infeksi dan merupakan faktor risiko COVID-19 akibat gula darah tinggi, gangguan pada kekebalan tubuh, komplikasi vaskular dan penyakit penyerta seperti dyslipidemia, hipertensi, dan penyakit kardiovaskular. Salah satu mekanisme yang mungkin melandasi hubungan DM dengan COVID-19 adalah adanya mekanisme peradangan kronis, gangguan respons kekebalan, peningkatan aktivitas pembekuan darah dan potensi kerusakan langsung SARS-CoV-2 ke pankreas. ${ }^{9}$

Tingkat keparahan dan mortalitas COVID-19 pada pasien diabetes secara signifikan lebih tinggi daripada pasien nondiabetes. Hal ini disebabkan karena pada pasien dengan komorbid terjadi penurunan fungsi kekebalan tubuh sehingga meningkatkan faktor risiko COVID-19. Selain itu, penderita diabetes juga telah dikaitkan dengan meningkatnya jumlah pasien rawat inap dan penerimaan pasien unit perawatan intensif (ICU). Oleh karena itu, selama pandemi COVID-19, penderita penyakit diabetes mellitus bisa menjadi masalah yang serius. ${ }^{10}$ Tujuan literature review ini adalah untuk mengetahui faktor risiko terjadinya COVID-19 pada pasien diabetes melitus agar dapat digunakan sebagai pertimbangan pengendalian faktor risiko seperti pengetatan protokol kesehatan serta perawatan pasien COVID-19 dengan komorbid dapat dilakukan dengan lebih baik.

\section{METODOLOGI}

Metode yang digunakan dalam penelitian ini adalah literature review dengan menggunakan jurnal nasional maupun internasional. Penelusuran literatur dilakukan melalui database PubMed, NCBI, dan Google Scholar. Penelitian ini melibatkan sebanyak 24 sumber pustaka dari tahun 2020-2021. Jurnal yang digunakan dalam penelitian ini adalah yang membahas tentang faktor risiko terjadinya COVID-19 pada pasien dengan komorbid diabetes melitus. Pencarian Jurnal dilakukan dengan menggunakan kata kunci Diabetes Mellitus, Comorbid, COVID-19, Clinical Symptom dan Risk Factor. Proses pembuatan Artikel ini melalui proses identifikasi, dinilai, lalu diinterpretasi semua temuan penelitian untuk menjawab setiap pertanyaan penelitian dengan cara merangkum hasil penelitian. 


\section{HASIL DAN PEMBAHASAN Definisi}

Coronavirus Disease 2019 atau COVID19 merupakan penyakit infeksi yang akibat SARS-CoV-2, yang memiliki kekerabatan yang dekat dengan virus SARS. dahulu Human coronaviruse (HCoVs) dianggap salah satu jenis virus yang tidak berbahaya yang menyebabkan flu biasa. Virus HCoVs pernah menyebabkan endemik sebelumnya yang tercatat mortalitas dan morbiditasnya cukup tinggi: Severe Acute Respiratory Syndrome (SARS-CoV) serta Middle East Respiratory Syndrome (MERS$\mathrm{CoV}$ ) pada beberapa tahun yang lalu. Akumulasi kasus MERS-CoV dan SARS-CoV sekitar 10.000 yang terdiri atas lebih dari 1000 kasus MERS-CoV dan lebih dari 8000 kasus SARSCoV. Rata-rata mortalitas yang diakibatkan oleh SARS-CoV adalah $10 \%$ sedangkan MERS-CoV lebih tinggi, sekitar $40 \%$. $^{11}$

COVID-19 merupakan virus yang sangat berbahaya terbukti dengan pernyataan WHO yang mengatakan bahwa virus ini merupakan pandemi global setelah jumlah infeksi di seluruh dunia mencapai lebih dari 121.000 kasus. Berdasarkan jumlah total kematian dibandingkan total kasus saat ini, angka kematian akibat kasus ini sekitar 2-3\%. Namun, angka kematian tersebut belum dapat dipastikan karena data masih terus berubah. ${ }^{11}$

\section{Epidemiologi}

Pada tanggal 2 Maret 2020 kasus pertama di Indonesia dilaporkan dan jumlahnya kian bertambah sampai dengan sekarang. Terhitung hingga tanggal 29 Mei 2021 Kemenkes melaporkan 1.809.926 kasus positif dan dengan 50.262 kasus meninggal yang tersebar hingga 34 provinsi di Indonesia. Tercatat kasus COVID-19 terjadi direntang usia <5->65 tahun. Kasus paling tinggi ada pada rentang usia 25 hingga 34 tahun dan paling rendah pada usia 0 hingga 5 tahun. ${ }^{12}$

CDC China melaporkan bahwa kasus yang paling tinggi terjadi pada pria sekitar $51,4 \%$ pada usia 30-79 tahun dan paling sedikit terjadi pada usia $<10$ tahun (1\%). Sebanyak $81 \%$ kasus merupakan kasus yang ringan, $14 \%$ parah, dan 5\% kritis. ${ }^{13}$ Temuan utama penelitian adalah sebagai berikut. Pertama, diabetes muncul pada $26,6 \%$ pasien yang dirawat di rumah sakit dengan COVID-19; Proporsi ini jauh lebih tinggi daripada prevalensi diabetes di wilayah rujukan RS Universitas Amiens (5,53\% pada 2013 dan $\approx 6 \%$ pada 2016). Kedua, COVID-19 dengan diabetes secara signifikan dikaitkan dengan kemungkinan lebih besar masuk ke ICU (relatif terhadap COVID-19 tanpa diabetes) tetapi tidak dikaitkan dengan peningkatan mortalitas. Ketiga, COVID-19dengan diabetes juga dikaitkan dengan risiko yang lebih tinggi untuk mengembangkan ARDS dan cedera ginjal akut, dibandingkan dengan COVID-19 tanpa diabetes. Terakhir, median lama rawat inap pada pasien COVID-19 dengan diabetes lebih lama dibandingkan pada pasien COVID-19 tanpa diabetes. ${ }^{10}$

Penyakit komorbid/bawaan juga mempengaruhi tingkat mortalitas. Presentase 10,5\% pada pasien COVID-19 dengan penyakit kardiovaskular, 7,3\% dengan diabetes, 6,3\% pada pasien dengan penyakit paru kronis, 6\% pada pasien dengan penyakit hipertensi, dan $5,6 \%$ pada pasien kanker. ${ }^{6}$

\section{Etiologi}

Coronavirus Disease 2019 (COVID-19) adalah penyakit infeksi disebabkan oleh SARS$\mathrm{CoV}-2$, yang memiliki bentuk dan perilaku menyerupai virus SARS. Coronavirus merupakan virus RNA strain tunggal positif, berkapsul dan tidak bersegmen. Mereka dikategorikan dalam empat kelompok, berdasarkan analisis filogenetik dan kriteria antigenik, khususnya: (a) alpha-CoVs, bertanggung jawab atas gangguan pencernaan pada manusia, anjing, babi, dan kucing; (b) beta$\mathrm{CoV}$, termasuk virus Corona pada elelawar (BCOV), Severe Acute Respiratory Syndrome (SARS) pada manusia, dan virus Middle Eastern Respiratory Syndrome (MERS); (c) gammaCoVs, yang menginfeksi spesies burung dan delta-coronavirus (deltaCoV). ${ }^{14}$

Coronavirus merupakan jenis virus rantai tunggal yang berukuran 120-160 nm. Utamanya virus ini menginfeksi pada hewan, seperti unta dan kelelawar. Ada 6 jenis coronavirus sebelum wabah COVID-19 yang dapat mengakibatkan 
penyakit pada manusia, diantaranya alphacoronavirus 229E, alphacoronavirus NL63, betacoronavirus OC43, betacoronavirus HKU1, Severe Acute Respiratory Illness Coronavirus (SARS-CoV), dan Middle East Respiratory Syndrome Coronavirus (MERS$\mathrm{CoV})$. Dari analisis filogenetik didapatkan bahwa virus ini memiliki genus yang sama dengan betacoronavirus dan subgenus coronavirus yang merupakan penyebab wabah SARS pada 2002-2004 lalu yaitu Sarbecovirus. Untuk itu, International Committee on Taxonomy of Viruses menyarankan nama SARS-CoV-2. ${ }^{22}$

Virulensi dari coronavirus memiliki hubungan dengan protein struktural dan protein non struktural. Coronavirus memiliki messenger RNA (mRNA) untuk membantu translasi dari proses transkripsi/replikasi. Gen yang berperan dalam transkripsi/replikasi ini terdiri $2 / 3$ dari rangkaian RNA 5'-end dan dua Open Reading Frame, ialah ORF1a dan ORF1b. Bagian 1/3 lainnya dari rangkaian RNA virus, yang tidak berperan dalam proses replikasi/transkripsi, berperan dalam mengkode 4 protein struktural, yaitu protein $\mathrm{S}$ (spike), protein $\mathrm{E}$ (envelope), protein $\mathrm{M}$ (membrane), dan protein $\mathrm{N}$ (nucleocapsid). ${ }^{4}$

Pada protein $\mathrm{S}$ betacoronavirus terdapat domain receptor binding yang memediasi rangkaian interaksi reseptor pada sel inang dan juga virus. Setelah ikatan tersebut terbentuk, protease yang terdapat di inang akan memecah protein $\mathrm{S}$ virus yang selanjutnya dan akan menyebabkan terjadinya fusi protein $\mathrm{S}$ yang memfasilitasi virus tersebut masuk ke dalam tubuh inang. ${ }^{16}$

\section{Patogenesis}

Virus dapat melewati membran mukosa, terutama mukosa nasal dan laring, kemudian memasuki paru-paru melalui traktus respiratorius. Protein S pada SARS-CoV-2 memfasilitasi masuknya virus corona ke dalam sel target. ${ }^{4}$ Hingga kini penelitian menjelaskan proses masuknya COVID-19 ke dalam sel memiliki kemiripan dengan SARS, didasarkan karna adanya kesamaan struktur hingga $76 \%$. Sehingga target virus ini diperkirakan adalah
Angiotensin Converting Enzyme 2 (ACE2) yang terdapat pada paru normal manusia dan diekspresikan pada alveolar tipe I dan II sebagai reseptor virus untuk masuk. Masuknya virus bergantung pada kemampuan virus untuk berikatan dengan ACE2, yaitu reseptor membran ekstraselular yang bergantung pada priming protein S ke protease selular, yaitu TMPRSS2. ${ }^{17}$

SARS-CoV masuk ke dalam sel dimulai saat terjadinya fusi membran virus dengan plasma membran sel tersebut. Protein S2' memiliki perang yang penting dalam pembelahan proteolitik yang memfasilitasi proses fusi membrane. Selain itu, terdapat clathrin dependent dan clathrin independent endocytosis yang memfasilitasi SARS-CoV untuk masuk ke dalam sel inang. ${ }^{18}$

Mekanisme yang sama dengan SARSCoV, yaitu pada SARS-CoV-2 setelah virus berhasil masuk dalam sel inang, genom RNA virus segera dikeluarkan ke sitoplasma lalu ditranslasikan menjadi 2 poliprotein dan protein struktural. Genom virus ini akan memulai replikasi, lalu selubung virus yang baru saja terbentuk memasuki membran retikulum endoplasma atau badan golgi dan dilanjutkan dengan pembentukan nukleokapsida. Partikel virus ini akan terus tumbuh ke dalam retikulum endoplasma, lalu vesikel yang terdiri atas partikel virus akan fusi dengan membran plasma untuk nantinya melepaskan komponenkomponen virus yang baru. ${ }^{19}$

Periode inkubasi pada COVID-19 adalah berkisar 3-14 hari. Diawali dengan pasien yang belum mengalami gejala ataupun kadar limfosit dan leukosit yang cenderung normal atau bahkan sedikit tutun. Lalu, virus akan menyebar secara hematogen dengan target utama adalah organ yang mengeskpresikan ACE-2 disaat ini pasien dapat merasakan gejalan yang ringan.

Dari gejala awal 4 hingga 7 , kondisi pasien dapat mulai terjadi perburukan yang ditandai dengan adanya sesak, menurunnya kadar limfosit, dan perburukan gambaran lesi di lapang paru pasien. Jika paada fase ini perburukan tidak dapat teratasi, dapat terjadi Acute Respiratory Distress Syndrome (ARSD), sepsis, hingga komplikasi lain. Gejala klinis yang memburuk dapat berhubungan dengan usia 
pasien (>70 tahun), penyakit bawaan yang dimiliki pasien seperti penyakit diabetes mellitus, darah tinggi dan obesitas. ${ }^{4}$

Selain itu, pelepasan sitokin secara besarbesaran menghasilkan "badai sitokin" yang pada gilirannya, dapat menyebabkan sindrom gangguan pernapasan akut, kegagalan pernapasan, kegagalan organ, dan kemungkinan kematian pasien. ${ }^{17}$ Faktor virus dan pejamu memiliki peran dalam infeksi SARS-CoV.35 Efek sitopatik virus dan kemampuannya mengalahkan respons imun menentukan keparahan infeksi. Disregulasi sistem imun kemudian berperan dalam kerusakan jaringan pada infeksi SARS-CoV-2. Respons imun yang tidak adekuat menyebabkan replikasi virus dan kerusakan jaringan. Di sisi lain, respons imun yang berlebihan dapat menyebabkan kerusakan jaringan. ${ }^{20}$

\section{Manifestasi Klinis}

Spektrum klinis COVID-19 bisa sangat heterogen. Kebanyakan orang dewasa dan anakanak menunjukkan gejala mirip flu ringan, tetapi beberapa dapat dengan cepat berkembang menjadi sindrom gangguan pernapasan akut (ARDS), gagal napas, aritmia, cedera jantung akut, syok, kegagalan banyak organ, dan kematian. ${ }^{1}$ Gejala yang paling sering dilaporkan adalah demam, batuk, kelelahan, produksi dahak dan sesak napas. Namun, sakit kepala, gejala pernapasan atas (misalnya sakit tenggorokan dan rinore) dan gejala gastrointestinal (misalnya mual dan diare) lebih jarang terjadi. Gangguan bau dan rasa (misalnya, anosmia dan dysgeusia) juga sering ditemukan pada pasien dengan COVID-19. ${ }^{1,5}$

Beberapa kesamaan manifestasi klinis antara infeksi SARS-CoV-2 dan infeksi betacoronavirus jenis sebelumnya, yaitu SARSCoV serta MERS-CoV diantaranya adalah demam, batuk kering, dan adanya gambaran opasifikasi ground-glass pada rontgen. Manifestasi klinis yang berhubungan dengan infeksi COVID diantaranya: (1) Penyakit tanpa komplikasi artinya pasien dengan gejala nonspesifik yaitu seperti demam, batuk, nyeri pada tenggorokan, nyeri otot, nyeri kepala, lemah, dan hidung tersumbat. Pada pasien dengan immuno compromised perlu diwaspadai adanya; (2) Pneumonia ringan , yaitu pasien dengan pneumonia ringan tanpa adanya gejala pneumonia berat; (3) Pneumonia berat yaitu penumonia dengan demam infeksi saluran napas ditambah dengan salah satu kriteria berikut yaitu frekuensi napas > 30 per menit, dan saturasi oksigen $(\mathrm{SpO} 2)<90 \%$ pada udara kamar atau terjadinya distress pernapasan yang berat; (4) Acute Respiratory Distress Syndrome (ARDS); (5) Sepsis yaitu pasien yang mengalami disfungsi organ yang mengancam nyawa disebabkan karena disregulasi respon tubuh terhadap infeksi. ${ }^{21}$

Pada hasil pemeriksaan laboratorium, sebagian besar penderita mengalami penurunan jumlah sel darah putih, terutama limfositopenia. ${ }^{16}$ Namun, pada pasien yang parah, jumlah neutrofil, penanda inflamasi, Ddimer, urea darah, dan kadar kreatinin umumnya lebih tinggi, dengan penurunan jumlah limfosit lebih lanjut. ${ }^{16}$ Tomografi komputer dada (CT) paling sering menunjukkan kekeruhan ground-glass dengan atau tanpa kelainan konsolidasi, lebis sering bilateral, dengan distribusi perifer dan melibatkan lobus bawah. Sementara beberapa kasus yang dikonfirmasi mungkin menunjukkan gambar CT yang normal. ${ }^{16}$

\section{Penularan}

Virus corona menyebar melalui hewan/zoonosis, sehingga ada kemungkinkan corona berasal dari hewan yang kemudian ditularkan ke manusia. Belum diketahui proses penularan COVID-19 ini secara pasti bagimana mekanisme penularan dari hewan ke manusia. Namun dari hasil penelitian terkini didapakan data yang menunjukkan penularan COVID-19 yaitu antar manusia ke manusia (human to human), yang diprediksi ditularkan melalui, droplet (percikan), melalui udara (airborne), fomit, fekal-oral, melalui darah, dan dari ibu ke anak. $^{22}$

\section{Faktor Risiko}

Berdasarkan penelitian, faktor risiko COVID-19 antara lain hipertensi, diabetes, pria dan perokok aktif menjadi faktor risiko 
terinfeksi COVId-19. Diyakini bahwa semakin besar distribusi gender laki-laki, semakin tinggi prevalensi perokok aktif. Pada perokok aktif, penderita darah tinggi serta diabetes melitus diduga terjadi peningkatan ekspresi dari reseptor ACE2..

Faktor risiko lainnya yang disebutkan oleh Centers for Disease Control and Prevention (CDC) adalah kontak erat, seperti tinggal di satu rumah dengan pasien COVID-19 dan adanya riwayat bepergian ke daerah yang memiliki indeks kasus yang tinggi. Sedangkan risiko rendah ialah saat beradaa di satu lingkungan namun tidak berkontak erat (berjarak 2 meter). Kelompok dengan risiko tinggi adalah tenaga medis. Sekitar 9\% kasus COVID-19 di Italia menginfeksi tenaga medis. Di China, lebih dari 3.300 tenaga medis terinfeksi COVID-19, dengan tingkat kematian $0,6 \% .^{24}$

\section{Faktor Risiko pada Penderita Diabetes Melitus}

Di antara pasien Covid-19, penyakit penyerta yang paling banyak salah satunya adalah diabetes. Diabetes adalah salah satu penyebab utama kesakitan dan kematian di seluruh dunia. Kondisi ini terkait dengan beberapa komplikasi makrovaskular dan mikrovaskuler, yang pada akhirnya berdampak pada kelangsungan hidup pasien secara keseluruhan. Hal tersebut menunjukkan bahwa penderita diabetes berisiko tinggi terkena COVID-19. Baik diabetes mellitus tipe 1 atau pun tipe 2 sama-sama dapat menyebabkan peningkatan glukosa. Tingkat glukosa yang tinggi cenderung dapat memperburuk penyakit yang dimiliki termasuk COVID-19 itu sendiri. Hal ini disebabkan karena kadar glukosa yang tinggi dapat memengaruhi kemampuan virus untuk dapat menginfeksi manusia, meningkatkan risiko peradangan hingga memperburuk system imun tubuh. 16

Studi yang dilakukan oleh Weina Guo et al. Sampai pada kesimpulan yang sama, studi tersebut menemukan bahwa 24 pasien Covid-19 tanpa penyakit penyerta selain diabetes mengembangkan pneumonia berat, pelepasan enzim yang berhubungan dengan kerusakan jaringan, peradangan, dan gangguan metabolisme glukosa. Selain itu, kadar serum biomarker yang terkait dengan inflamasi, seperti IL-6, protein Creactive, serum ferritin, dan indeks koagulasi, D-dimer, meningkat secara signifikan $(\mathrm{P}(\mathrm{P}<0,01)$ pada pasien diabetes dibandingkan dengan mereka yang tidak diabetes. Hal ini menunjukkan bahwa pasien dengan diabetes lebih rentan terhadap inflamasi yang pada akhirnya mengarah pada risiko Covid-19 yang lebih cepat. ${ }^{23}$

Diabetes yang merupakan $\begin{array}{r}\text { kondisi } \\ \text { hiperinflamasi dan tampaknya }\end{array}$
meningkatkan kerentanan
secara independen dari penyakit lain yang mendasari. Ada beberapa kemungkinan mekanisme: (a) peradangan kronis, (b) keadaan hiperkoagulasi, dan (c) aktivasi sistem reninangiotensin-aldosteron (RAAS) dan disregulasi sistem saraf simpatis. ${ }^{18}$ Diabetes yang merupakan kondisi peradangan kronis yang ditandai dengan beberapa kelainan metabolik dan vaskular yang dapat memengaruhi respons tubuh terhadap patogen. Hiperglikemia dan resistensi insulin meningkatkan sintesis produk akhir glikosilasi (AGEs) dan sitokin proinflamasi, stres oksidatif, selain merangsang produksi molekul adhesi yang memediasi peradangan jaringan. Proses peradangan ini dapat membentuk mekanisme yang mendasari yang mengarah pada kecenderungan yang lebih tinggi terhadap infeksi, dengan hasil yang lebih buruk pada pasien dengan diabetes. ${ }^{16}$

Pada DMT2, selain proses peradangan yang ditandai yang telah dibahas sebelumnya, terjadi ketidakseimbangan antara koagulasi dan fibrinolisis, dengan peningkatan kadar faktor pembekuan dan penghambatan relatif sistem fibrinolitik. Baik resistensi insulin dan DMT2 dikaitkan dengan disfungsi endotel, dan peningkatan agregasi dan aktivasi trombosit. Kelainan ini mendukung perkembangan keadaan pro-trombotik hiperkoagulasi. Selain itu, aterosklerosis, peradangan vaskular, dan disfungsi endotel juga merupakan bagian dari patogenesis kondisi kronis lainnya, misalnya hipertensi dan CVD. Pasien dengan COVID-19 biasanya menunjukkan limfositopenia, trombositopenia dan leukopenia pada tingkat 
yang lebih rendah, yang lebih menonjol di antara mereka dengan penyakit parah. ${ }^{16}$

Selain itu, sebagian besar parameter inflamasi (protein C-reaktif, feritin serum, laju sedimentasi eritrosit, dan interleukin-6) dan faktor pro-koagulan (D-dimer dan fibrinogen) juga secara signifikan lebih tinggi di antara pasien diabetes tanpa penyakit penyerta lainnya. Lebih lanjut, pasien diabetes dengan faktor inflamasi yang meningkat dan hiperkoagulabilitas lebih mungkin berkembang menjadi prognosis yang lebih buruk. Oleh karena itu, penderita diabetes membutuhkan perhatian yang lebih intensif dan harus diawasi secara ketat karena adanya risiko kerusakan yang cepat. ${ }^{18}$

\section{SIMPULAN DAN SARAN}

COVID-19 telah menyebar dengan cepat sejak identifikasi awal di Wuhan dan telah menunjukkan spektrum keparahan yang luas. Isolasi dini, diagnosis dini, dan manajemen dini mungkin secara kolektif berkontribusi pada pengendalian penyakit dan hasil yang lebih baik. Diabetes merupakan faktor risiko signifikan dari kesakitan dan kematian pada pasien dengan COVID-19. Peningkatan risiko kesakitan dan kematian disebabkan oleh peradangan kronis, keadaan hiperkoagulasi, perubahan ekspresi reseptor ACE2, potensi kerusakan langsung pankreas, disregulasi jumlah dan aktivitas sel imun, disfungsi alveolar, dan disfungsi endotel.

Penderita diabetes memiliki risiko tinggi terkena Covid-19. Baik diabetes tipe 1 atau tipe 2 bisa menyebabkan gula darah naik. Gula darah tinggi dapat memperburuk penyakit yang sudah ada termasuk Covid-19. Ini karena gula darah tinggi memengaruhi kemampuan virus untuk menginfeksi manusia. Diabetes juga meningkatkan risiko peradangan dan memperburuk daya tahan tubuh, dan penderita diabetes lebih rentan terhadap inflamasi yang pada akhirnya mengarah pada risiko Covid-19 yang lebih cepat. Diabetes dan penyakit penyerta lainnya merupakan prediktor signifikan dari morbiditas dan mortalitas pada pasien dengan COVID-19. Penelitian di masa depan sangat diperlukan untuk memberikan pemahaman yang lebih baik mengenai perbedaan potensial dalam kecenderungan genetik di seluruh populasi, mekanisme patofisiologis yang mendasari hubungan antara COVID19 dan diabetes, dan manajemen klinisnya.

\section{UCAPAN TERIMA KASIH}

Penulis mengucapkan terima kasih kepada semua pihak yang telah membantu proses penulisan jurnal hingga terselesaikannya penelitian ini.

\section{REFERENSI}

1. Rees EM, Nightingale ES, Jafari Y, Waterlow NR, Clifford SB, Pearson CA, Group CW, Jombart T, Procter SR, Knight GM. COVID-19 length of hospital stay : a systematic review and data synthesis. BMC medicine. 2020;18(1):270.

2. Wang L, He W, Yu X, Hu D, Bao M, Liu H, Zhou J, Jiang H. Coronavirus disease 2019 in elderly patients: Characteristics and prognostic factors based on 4-week follow-up. The Journal of infection. 2020; 80(6) : 639-645.

3. Argenziano MG, Bruce SL, Slater CL, Tiao JR, Baldwin MR, Barr RG, et al. Characterization and clinical course of 1000 patients with coronavirus disease 2019 in New York: retrospective case series. BMJ (Clinical research ed.). 2020; 369:1996.

4. Imam Z, Odish F, Gill I, O'Connor D, Armstrong $\mathrm{J}$, Vanood A, et al. Older age and comorbidity are independent mortality predictors in a large cohort of 1305 COVID-19 patients in Michigan, United States. Journal of internal medicine. 2020; 288(4) : 469-476.

5. Mishra V, Burma AD, Das SK, Parivallal MB, Amudhan S, Rao GN. COVID-19-Hospitalized Patients in Karnataka: Survival and Stay Characteristics. Indian journal of public health. 2020; 64: 221-224.

6. Moriconi D, Masi S, Rebelos E, Virdis A, Manca $\mathrm{ML}$, De Marco S, et al. Obesity prolongs the hospital stay in patients affected by COVID-19, and may impact on SARS-COV-2 shedding. Obesity research \& clinical practice. 2020; 14(3): 205-209.

7. Iavarone M, D'Ambrosio R, Soria A, Triolo M, Pugliese N, Del Poggio P, et al. High rates of 30day mortality in patients with cirrhosis and COVID-19. Journal of hepatology. 2020; 73(5) : 1063-1071.

8. Lovinsky-Desir S, Deshpande DR, De A, Murray 
L, Stingone JA, Chan A, et al. Asthma among hospitalized patients with COVID-19 and related outcomes. The Journal of allergy and clinical immunology. 2020; 146(5):1027-1034.e4.

9. Roncon L, Zuin M, Rigatelli G, Zuliani G. Diabetic patients with COVID-19 infection are at higher risk of ICU admission and poor short-term outcome. Journal of clinical virology:the official publication of the Pan American Society for Clinical Virology. 2020; 127:104354.

10. Al-Salameh A., Lanoix JP, Bennis Y, Andrejak C, Brochot E, Deschasse G, et al. Characteristics and outcomes of COVID-19 in hospitalized patients with and without diabetes. Diabetes/metabolism research and reviews. 2021; 37(3):e3388.

11. Motta I, Centis R., D'Ambrosio L, García JM, Goletti D, Gualano G, et al. Tuberculosis, COVID-19 and migrants: Preliminary analysis of deaths occurring in 69 patients from two cohorts. Pulmonology. 2020; 26(4):233-240.

12. Zhang, JJ, Cao YY, Tan G, Dong, X, Wang B C, Lin J, et a. Clinical, radiological, and laboratory characteristics and risk factors for severity and mortality of 289 hospitalized COVID-19 patients. Allergy. 2021; 76(2): 533-550.

13. Bhatti R, Khamis AH, Khatib S, Shiraz S, Matfin G. Clinical Characteristics and Outcomes of Patients With Diabetes Admitted for COVID-19 Treatment in Dubai: Single-Centre CrossSectional Study. JMIR public health and surveillance. 2020; 6(4):e22471.

14. Liu X, Zhou H, Zhou Y, Wu X, Zhao Y, Lu Y, et al. Risk factors associated with disease severity and length of hospital stay in COVID-19 patients. The Journal of infection. 2020; 81(1) : e95-e97.

15. Blanco JL, Ambrosioni J, Garcia F, Martínez E, Soriano A, Mallolas J, et al COVID-19 in patients with HIV: clinical case series. The lancet. HIV. 2020; 7(5): e314-e316.

16. Hussain A, Bhowmik B, do Vale Moreira NC. COVID-19 and diabetes: Knowledge in progress. Diabetes research and clinical practice. 2020; 162: 108142.

17. Muniyappa R, Gubbi S. COVID-19 pandemic, coronaviruses, and diabetes mellitus. American journal of physiology. Endocrinology and metabolism. 2020; 318(5): E736-E741.

18. Tadic M, Cuspidi C, Sala C. COVID-19 and diabetes: Is there enough evidence? Journal of clinical hypertension (Greenwich, Conn.). 2020; 22(6):943-948.

19. Abdi A, Jalilian M, Sarbarzeh PA, Vlaisavljevic Z. Diabetes and COVID-19: A systematic review on the current evidences. Diabetes research and clinical practice. 2020; 166: 108347.

20. Kumar A, Arora A, Sharma P, Anikhindi SA, Bansal N, Singla V, et al. Is diabetes mellitus associated with mortality and severity of COVID19? A meta-analysis. Diabetes \& metabolic syndrome. 2020; 14(4): 535-545.

21. Bloomgarden ZT. Diabetes and COVID19. Journal of diabetes. 2020; 12(4):347-348.

22. Gorbalenya AE, Baker SC, Baric RS, de Groot, RJ, Drosten C, Gulyaeva AA., et al. The species Severe acute respiratory syndrome-related coronavirus: classifying 2019-nCoV and naming it SARS-CoV-2. Nat Microbiol. 2020; published online March 2.

23. Guo YR, Cao QD, Hong ZS, Tan YY, Chen, SD, Jin, HJ, dkk. Asal, penularan, dan terapi klinis wabah penyakit coronavirus 2019 (COVID-19) pembaruan status. Mil Med Res 2020; 7 (1): 11.https://doi.org/10.1186/ s40779-02000240-0. EPub 2020/03/15. PubMed PMID: 32169119; PMCID Pusat PubMed: PMCPMC7068984.

24.Zhang, C., Shi, L., Wang, F.S. Liver injury in COVID-19: management and challenges. Lancet Gastroenterol Hepatol. 2020. Available from: DOI: $10.1016 / \mathrm{S} 2468-1253(20) 30057-1$. 